\title{
Use of Immunomagnetic Separation for the Detection of Desulfovibrio vulgaris from Environmental Samples
}

\author{
Romy Chakraborty ${ }^{\mathrm{a}}$, Terry C. Hazen ${ }^{\mathrm{a}}$, , Dominique C. Joyner $^{\mathrm{a}}$, Kirsten Küsel ${ }^{\mathrm{b}}$, Mary E. Singer ${ }^{\mathrm{a}}$, \\ Jana Sitte $^{\mathrm{b}}$, Tamas Torok ${ }^{\mathrm{a}}$ \\ ${ }^{a}$ Lawrence Berkeley National Laboratory, Berkeley CA, United States \\ ${ }^{b}$ Friedrich Schiller University, Jena, Germany
}

\begin{abstract}
Immunomagnetic separation (IMS) has proved highly efficient for recovering microorganisms from heterogeneous samples. Current investigation targeted the separation of viable cells of the sulfate-reducing bacterium, Desulfovibrio vulgaris. Streptavidin-coupled paramagnetic beads and biotin labeled antibodies raised against surface antigens of this microorganism were used to capture $D$. vulgaris cells in both bioreactor grown laboratory samples and from extremely low-biomass environmental soil and subsurface drilling samples. Initial studies on detection, recovery efficiency and viability for IMS were performed with laboratory grown $D$. vulgaris cells using various cell densities. Efficiency of cell isolation and recovery (i.e., release of the microbial cells from the beads following separation) was followed by microscopic imaging and acridine orange direct counts (AODC). Excellent recovery efficiency encouraged the use of IMS to capture Desulfovibrio spp.cells from low-biomass environmental samples. The environmental samples were obtained from a radionuclide-contaminated site in Germany and the chromium (VI)-contaminated Hanford site, an ongoing bioremediation project of the U.S. Department of Energy Field deployable IMS technology may greatly facilitate environmental sampling and bioremediation process monitoring and enable transcriptomics and proteomics/metabolomicsbased studies directly on cells collected from the field.
\end{abstract}

\section{Introduction}

Rapid detection of microorganisms is necessary for food safety, in clinical diagnostics and genetic engineering, in bioremediation or monitoring change in structure and function of a single microorganism or microbial communities in the environment. Immunomagnetic separation (IMS) is a rapid, specific, efficient, and technically simple method that can be used for the separation and enrichment of a target organism directly from a consortium of non-target organisms or other particles. Magnetic separation based techniques are widespread in food and medical microbiology (Chapman et al., 2001; Foddai et al., 2010; Olsvik et al., 1994; Uyttendaele et al., 2000; Wadud et al., 2010), especially for Listeria spp. (Gasanov et al., 2005). These procedures greatly reduce overall analysis time by eliminating culturing, plating, biochemical enzymatic tests, nucleic acid extraction and other molecular biology protocols. Immunology based detection systems, including but not limited to enzyme-linked immunosorbent assay (ELISA), colony immunblotting, direct immunofluorescent filter techniques, and several immunocapture techniques have gained in popularity over the years as a viable screening method towards detection of target microorganisms, especially since they do not destroy the sample being tested. IMS has been applied recently in various combinations of modern methods, for example with bioluminescence (Bushon et al. 2009; Su and Li, 2004), microfluidics (Qiu et al., 2009; Sivagnanam et al., 2010), PCR (Ayaz et al., 2009; Lindqvist et al., 1998; Mercanoglu and Griffiths, 2005), laboratory-on-a-chip systems (Beyor et al., 2009), or stable isotope probing (Miyatake et al., 2009).

Sulfate-reducing bacteria (SRB) couple the oxidation of substrates to the reduction of sulfate to sulfide (Rabus et al., 2006). They are versatile in their ability to use organic matter that includes simple organic acids like lactic, acetic, propionic, or other fatty acids, complex mono and polyaromatic petroleum hydrocarbons like BTEXs, naphthalene, phenols, as well as alkanes (Chakraborty and Coates, 2004; So and Young, 1999). SRB are ubiquitous-present in soil and sediment, fresh and marine waters, hot springs and geothermal springs, petroleum and natural gas wells, and in sewage_-playing important roles in biogeochemical processes and aiding in bioremediation of toxic wastes (Kaksonen et al., 2004; Perez et al., 2010; Wei and Finneran, 2009). However, they may also adversely affect industry by virtue 
of the end products of sulfate reduction. For example, SRB thrive in deep wells, plumbing systems, water softeners, and water heaters. By producing hydrogen sulfide the end product of sulfate reduction, they lend an undesirable rotten egg smell, thus compromising water quality. SRB are also responsible for corrosion of cast iron-stainless steel pipelines generously used in sewage treatment facilities and in petroleum reservoirs. U.S. losses as a result of SRB corrosion damage were estimated to be \$4-6 billion/year (Zuo et al., 2004).

Desulfovibrio vulgaris ( Dv) is a well-characterized sulfate-reducer known to reduce metals (Klonowska et al., 2008; Lovley, 1993; Phillips et al., 1995), and has commonly been detected in DOE contaminated sites through genomic tools. D. vulgaris and closely related SRB have been routinely found at the uranium-contaminated groundwater at the Field Research Center (FRC) and the chromiumcontaminated site at Hanford, WA (Chang et al., 2001; Chakraborty R. (http://www.ncbi.nlm.nih.gov/nuccore/CP002297.1); Hemme et al., 2010). To better comprehend the presence and activity of Dv or Dvlike microorganisms under these non-optimal conditions in-situ, it is imperative to examine the gene expression of these cells separated from their environment with minimal disruption or interference caused by cell processing. As part of our ongoing investigations on the stress and survival of SRB (namely Dv) in the environment (see more at vimss.lbl.gov), we developed and tested a non-destructive method that uses immunomagnetic separation (IMS) of the model sulfatereducing bacterium, D. vulgaris. Our ultimate goal is to develop a fielddeployable version of IMS that enables the detection of target microorganisms from often low biomass environmental samples to be then further processed in various -omics (e.g., transcriptomics and metabolomics) studies to better characterize the metabolic properties.

\section{Material and methods}

\subsection{Microbial strain selection and growth}

Laboratory experiments used batch or continuously growing bioreactor samples of $D$. vulgaris subs. vulgaris (Postgate and Cambell) ATCC 29579, also known as DSM 644 strain Hildenborough (DvH). Each culture run started from a glycerol stock maintained at $-80^{\circ} \mathrm{C}$. DvH cells were grown in LS4D medium (Mukhopadhyay et al., 2006) at $30^{\circ} \mathrm{C}$ in an anaerobic chamber (COY Laboratory Products, Grass Lake, MI), using $5 \% \mathrm{CO}_{2}, 5 \% \mathrm{H}_{2}$, and the balance $\mathrm{N}_{2}$. During microbial growth in the bioreactor, temperature, $\mathrm{pH}$, and optical density of the culture were continuously monitored and recorded. D. vulgaris strain $\mathrm{RCH} 1$ was grown in LS4D under a $\mathrm{N}_{2}$ headspace using 50-ml serum vials closed with thick butyl rubber stoppers and sealed with aluminum crimps and incubated either at $30^{\circ} \mathrm{C}$ or $37^{\circ} \mathrm{C}$.

\subsection{Environmental samples}

Environmental samples were included in the investigation from two different sites. Subsurface water samples were collected from the chromium (VI)-contaminated Hanford $100 \mathrm{H}$ site, an ongoing bioremediation project of the U.S. Department of Energy. Water was taken from the lactate injection well using a bailer at a depth of 46.5 feet. Serum bottles were degassed with nitrogen gas and autoclaved prior to filling. Samples were injected into the bottle with $60-\mathrm{ml}$ sterile syringe and $22 \mathrm{G}$ needle. The bottles were shipped on "blue ice" overnight to the laboratory for processing.

Soil samples were collected in February 2009 at the bank of the Gessenbach creek (E $45^{\circ} 10.121^{\prime}$ N 56 $35.807^{\prime}$ ) downstream from former mining sites near Ronneburg, Thuringia in Germany. The groundwater-influenced horizons Btlc and BrI are enriched in metals and radionuclides due to earlier mining activities (Burkhardt et al., 2010; Sitte et al., 2010). The collected samples were stored in sterile plastic bags and refrigerated until further processing.

\subsection{Antibody production and labeling}

Laboratory grown DvH cells were processed to yield O (surface) antigens. Briefly, cells were centrifuged at $10,322 \times \mathrm{g}$ for $10 \mathrm{~min}$ and resuspended in phosphate buffered saline (PBS) to obtain a cell density of $\sim 10^{9}$ cells $\mathrm{ml}^{-1}$. The cell suspension was then boiled for $5 \mathrm{~min}$ to release and degrade flagellar proteins. The resulting volume was preserved in PBS with $0.02 \%$ thimerosal (Sigma, St. Louis, MO). The preparation was then shipped to Pacific Immunology Corporation (Ramona, CA) for processing. The purified and quantified polyclonal antibodies obtained were aliquoted and stored at $-80^{\circ} \mathrm{C}$. Two hundred microliters of purified unconjugated antibodies at a concentration of $2.5 \mathrm{mg} \mathrm{ml}^{-1}$ were labeled with $6 \mu \mathrm{l}$ of the DSB-X biotin ligand following manufacturer's protocol (Molecular Probes, Invitrogen, Carlsbad, CA). DSB-X biotin, a derivative of desthiobiotin, a stable biotin precursor, has the ability to bind biotin-binding proteins such as streptavidin.

\subsection{Immunomagnetic separation}

\subsubsection{Cultured laboratory cells}

IMS was used to capture D. vulgaris ATCC 29579 (DvH) cells in laboratory-grown samples. The Dynabeads ${ }^{\circledR}$ FlowComp ${ }^{\text {TM }}$ Flexi kit and manufacturer's protocol (Invitrogen, Carlsbad, CA) were used in the separation with a slight modification. In short, in a $1.5-\mathrm{ml}$ microcentrifuge tube, $1 \mathrm{ml}$ of a growing DvH culture was harvested by centrifugation $\left(20,800 \times \mathrm{g}\right.$ for $1 \mathrm{~min}$ at $\left.4{ }^{\circ} \mathrm{C}\right)$. The pellet was resuspended in $500 \mu \mathrm{l}$ ice-cold Isolation Buffer and $25 \mu \mathrm{l}$ of DSB-X labeled antibody added. Rest of the manufacturer's protocol enclosed with the Dynabeads ${ }^{\circledR}$ FlowComp ${ }^{\mathrm{TM}}$ Flexi kit was strictly followed regarding addition of the isolation buffer, dynabeads, release buffer as well as the incubation periods and temperatures. There were two important exceptions: (a) the mixing and incubation times were increased to $30 \mathrm{~min}$, each, and (b) all necessary steps were performed in an anaerobic chamber, including the use of degassed sterile water to make up the working solution of the Isolation Buffer. Further, the separation steps were performed on ice/ice cold reagents to preserve the metabolic state of the cells and significantly reduce or halt cellular metabolism.

Also, a pilot lab consortium experiment was designed with a subsurface water sample from the DOE chromium (VI) bioremediation $100 \mathrm{H}$ site at Hanford, WA. Sterile-filtered subsurface injection well water sample was amended with a model microbial community (MMC) comprising of Geobacter metallireducens, D. vulgaris strain RCH1 (Chakraborty R. (http://www.ncbi.nlm.nih.gov/nuccore/CP002297.1)) and Pseudomonas stutzeri strain RCH2 (Han et al., 2010). The bacteria were grown overnight in appropriate media, i.e., anaerobic minimal basal medium with $10 \mathrm{mM}$ acetate and $10 \mathrm{mM}$ Fe-NTA for Geobacter metallireducens, LS4D for strain RCH1 and minimal basal medium with $10 \mathrm{mM}$ lactate and $10 \mathrm{mM}$ nitrate for strain $\mathrm{RCH} 2$ under anaerobic conditions. Once grown, bacterial cells were added to the water sample in 100-ml serum bottles prior to IMS treatment to reach a cell density of $3 \times 10^{6}$ cells $\mathrm{ml}^{-1}$. Ten milliliters of the amended water were harvested by centrifugation $\left(20,800 \times \mathrm{g}\right.$ for $1 \mathrm{~min}$ at $\left.4{ }^{\circ} \mathrm{C}\right)$ and the pellet resuspended in $500 \mu \mathrm{l}$ ice-cold Isolation Buffer for IMS. Rest of manufacturer's protocol was followed with the modifications as described above for the laboratory grown pure culture of DvH.

\subsubsection{Environmental samples}

IMS was also used to capture D. vulgaris and other Desulfovibrio spp. (similar to strain Hildenborough) from environmental samples collected at ongoing bioremediation project sites. All sample treatment and downstream processing steps were performed under anaerobic conditions and in the cold to arrest cells from further metabolism. Microorganisms were harvested from 100-ml subsurface injection well water samples in duplicates by centrifugation $\left(10,322 \times \mathrm{g}\right.$ for $10 \mathrm{~min}$ at $\left.4^{\circ} \mathrm{C}\right)$ and resuspended in $500 \mu \mathrm{l}$ of ice-cold 
Isolation Buffer (Dynabeads ${ }^{\circledR}$ FlowComp ${ }^{\mathrm{TM}}$ Flexi Kit; Invitrogen, Carlsbad, CA).

For the soil samples collected from the banks of the creek downstream of a mining site in Thuringia, Germany, suspensions were prepared in flasks containing $2000 \mathrm{ml}$ of $0.1 \%(\mathrm{w} / \mathrm{v})$ sodium pyrophosphate (Sigma, St. Louis, MO), each, using $1800 \mathrm{~g}$ and $2000 \mathrm{~g}$ soil for Btlc and BrI, respectively. After a 30-min mixing, soil particles were separated by centrifugation $(1000 \times \mathrm{g}$ for $10 \mathrm{~min}$ at room temperature). Microbial cells and fine soil particles harvested by centrifugation $\left(10,000 \times \mathrm{g}\right.$ for $20 \mathrm{~min}$ at $\left.15^{\circ} \mathrm{C}\right)$ were resuspended in $40 \mathrm{ml}$ of ice-cold Isolation Buffer. For downstream processing, $500 \mu \mathrm{l}$ of this suspension was used. IMS capturing and further processing followed the modified manufacturer's protocol (see under Section 2.4.1). Sulfate concentrations were measured spectrophotometrically (Tabatabai, 1974) in $0.45-\mu \mathrm{m}$ filtered 5 -week old sulfate-reducing enrichment cultures originating from the creek bank soil.

\subsubsection{IMS monitoring and quality control}

Microscopic imaging and acridine orange direct counting was used to monitor laboratory-grown DvH cells, environmental samples, and subsamples taken during IMS processing. Desulfovibrio cells have characteristic vibrio-shaped cell morphology and this feature was used to detect them in the samples collected during and after IMS processing. Cell densities were quantified by a modified acridine orange direct count (AODC) protocol. In short, IMS-separated cells were diluted in $1 \times$ phosphate buffered saline (PBS; Sigma, St. Louis, MO) to give a convenient cell density of about $10^{7}$ cells $\mathrm{ml}^{-1}$. Immediately, $10 \mu \mathrm{l}$ were spotted onto teflon-printed slides (Electron Microscopy Sciences (Hatfield, PA), air-dried and heat fixed, and stained with $25 \mu \mathrm{l}$ of acridine orange (Molecular Probes, Invitrogen, Carlsbad, CA). After 2 min incubation in the dark, the washed slides were mounted with non-fluorescent immersion oil (Carl Zeiss, Germany) and observed with FT510 filter in a fluorescent microscope (Axioscope, Carl Zeiss, Germany). This classic cell-permeating nucleic acid binding dye emits green fluorescence when bound to dsDNA and red fluorescence when bound to ssDNA or RNA. AOCD data were computed as cells $\mathrm{ml}^{-1}$.

Viability of separated cells was tested in LS4D broth or agar growing the cultures at $30{ }^{\circ} \mathrm{C}$ in the anaerobic chamber (see under Section 2.1).

Preliminary identification of the separated cells was achieved by real-time (RT) PCR using D. vulgaris species-specific 16S rRNA-coding gene targeting primers. Total genomic DNA was extracted from the separated cells using Gentra Puregene Yeast/Bacteria Kit (Qiagen, Valencia, CA) and manufacturer's protocol. The primers (Dv1F 5'-AAG ACC TTC CCG AAA AGG AA and Dv1R 5'-ACC AGA GTG CCC AGC ATT $A C$ ) were designed based on published sequences (cmr.jcvi.org/cgibin/CMR/GenomePage.cgi?org = gdv). The amplified fragment length is 155-bp. RT-PCR was performed with a MyiQ Single-Color Real-Time PCR Detection System using iQ SYBR Green Supermix, manufacturer's protocol, and iQ5 Optical System Software, Version 2.1 (Bio-Rad, Hercules, CA).

\section{Results and discussion}

\subsection{Cultured laboratory cells}

Serially diluted laboratory grown DvH cells were IMS processed to monitor efficacy of separation and recovery. As shown in Fig. 1A, DvH cells appeared as curved rods and well separated from each other in the absence of the beads. When treated with streptavidin-coupled paramagnetic beads, cells of DvH were only detected attached to the beads. No 'free-floating' cells were observed (Fig. 1B). The number of cells as measured by AODC pre-IMS processing matched well with the AODC counts post-IMS treatment. Similar efficiency of recovery was observed with a range of variously diluted culture of DvH. The



B

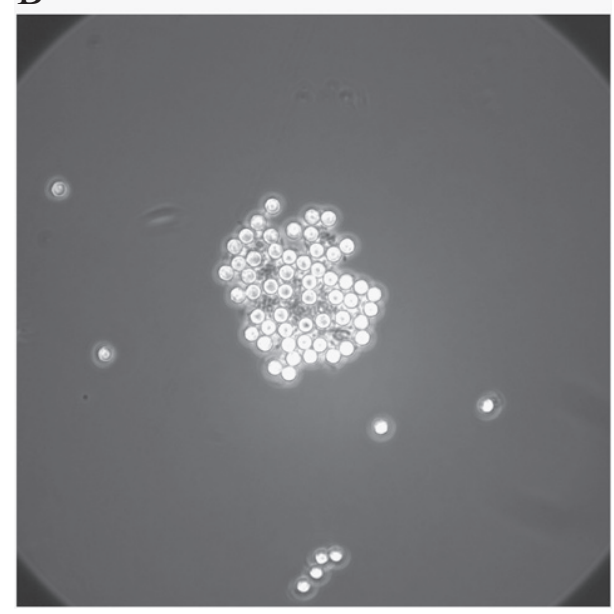

Fig. 1. A. Mid-log phase Desulfovibrio vulgaris (cells appear as curved rods). B. D. vulgaris cells attach to the surface of the streptavidin-coupled paramagnetic beads.

manufacturer's protocol is optimized for approximately $5 \times 10^{7}$ cells. However, under our experimental conditions excellent separation and recovery of DvH cells were observed in the range of $10^{5}-10^{8}$ cells $\mathrm{ml}^{-1}$ (Table 1). This result is promising and suggests that IMS of DvH may also be used in low-biomass environments.

\subsection{Laboratory consortium}

The pilot experiment was designed with subsurface injection well water from the DOE chromium (VI) bioremediation $100 \mathrm{H}$ site at Hanford, WA, wherein sterile-filtered water sample was amended with a model microbial community (MMC) comprised of Geobacter metallireducens, D. vulgaris strain RCH1 (Chakraborty R. (http://www.ncbi.nlm.nih.gov/nuccore/CP002297.1)) and Pseudomonas stutzeri strain RCH2

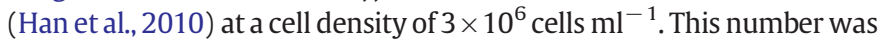
based on realistic cell densities observed in low-biomass water samples when collected from the field. The microorganisms were chosen as they

Table 1

Efficiency of serially diluted DvH cell isolation and recovery.

\begin{tabular}{lll}
\hline Dilution of DvH & AODC before IMS (cells ml ${ }^{-1}$ ) & AODC after IMS (cells ml ${ }^{-1}$ ) \\
\hline $1 \times$ & $1.5 \times 10^{8}$ & $1.3 \times 10^{8}$ \\
$10 \times$ & $3.2 \times 10^{7}$ & $1.8 \times 10^{7}$ \\
$100 \times$ & $3.4 \times 10^{6}$ & $1.1 \times 10^{6}$ \\
$1000 \times$ & $1.3 \times 10^{6}$ & $2.7 \times 10^{5}$ \\
\hline
\end{tabular}




\section{A}



B

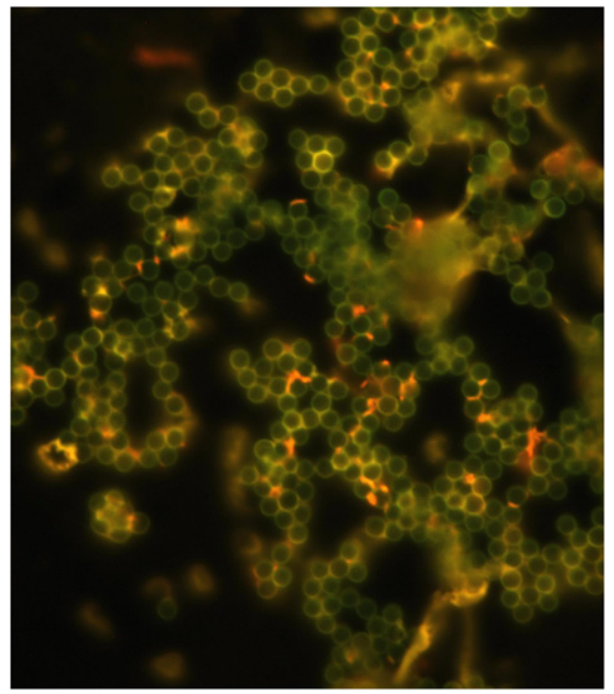

$\mathrm{C}$

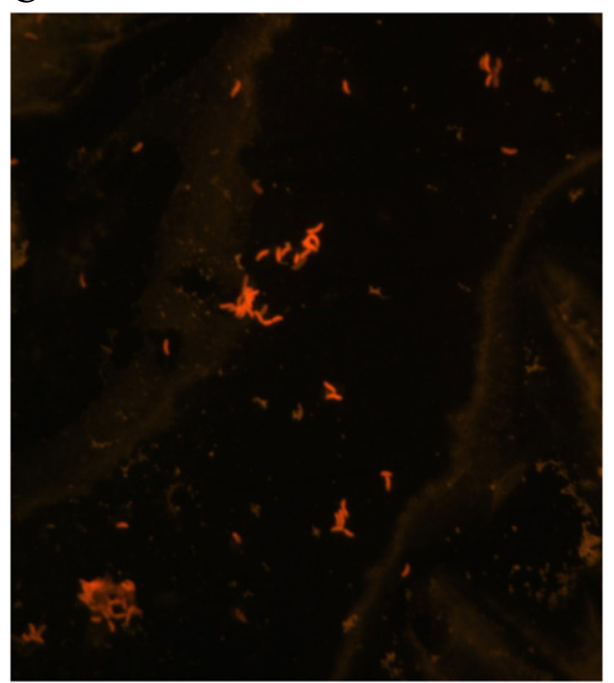

Fig. 2. A. Acridine orange stained image of lab consortia (MMC) in subsurface injection well water from $100 \mathrm{H}$ site at Hanford before IMS. B. Acridine orange stained image of curved Desulfovibrio strain RCH1 cells attached to paramagnetic beads. C. Acridine orange stained image of recovered $D$. vulgaris $\mathrm{RCH} 1$ cells post-IMS. represented the microbial community at the site as previously demonstrated by $16 \mathrm{~S}$ PhyloChip based analyses (Brodie et al., unpublished). P. stutzeri strain RCH2 and D. vulgaris strain $\mathrm{RCH} 1$ were actually isolated from the $100 \mathrm{H}$ site at Hanford during biostimulation tests, wherein a polylactate containing Hydrogen Release Compound

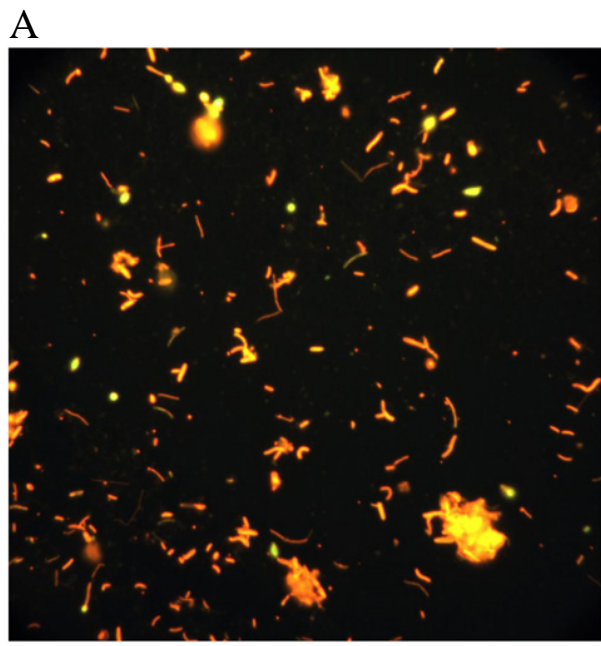

B

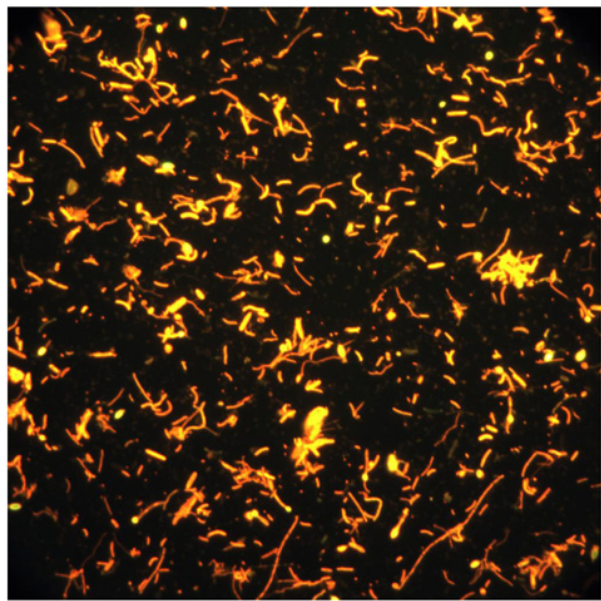

$\mathrm{C}$

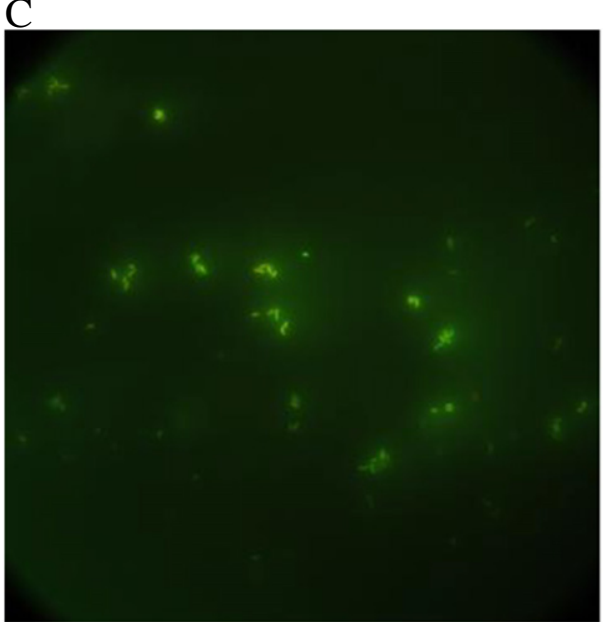

Fig. 3. A. Acridine orange stained image of the subsurface injection well water microbia community from the Hanford site. B. Acridine orange stained image of the subsurface injection well water microbial community from the Hanford site after concentration. C. Acridine orange stained image of the subsurface injection well water microbial community from the Hanford site after IMS separation. 


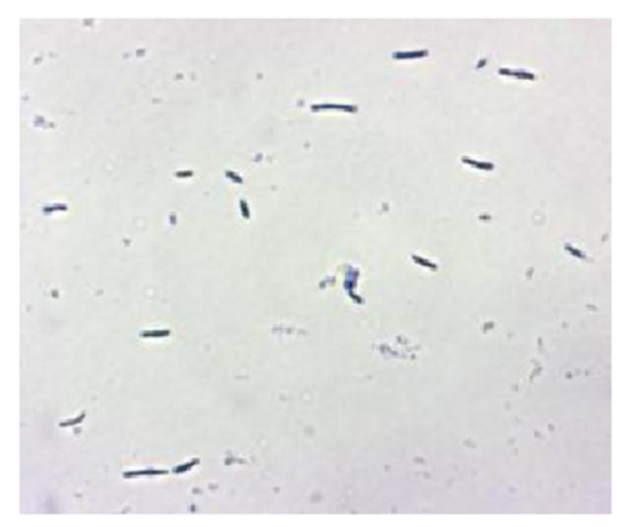

Fig. 4. Methylene blue stained Btlc enrichment culture following IMS treatment.

( HRC $^{\circledR}$; Regenesis, San Clemente, CA) was injected to stimulate $\mathrm{Cr}(\mathrm{VI})$ reduction. Acridine orange stained image of the water sample amended with the three microbial cultures revealed different cell morphologies characteristic of the individual cells: $D$. vulgaris strain $\mathrm{RCH} 1$ cells were vibrio-shaped, P. stutzeri strain RCH2 and G. metallireducens strain GS15 cells appeared as short rods (Fig. 2A). When the sample was treated with streptavidin-coupled paramagnetic beads, cells of Desulfovibrio strain RCH1 were detected attached to the beads (Fig. 2B). Completed IMS-treatment resulted in curved vibrio-shaped cells of $D$. vulgaris strain $\mathrm{RCH} 1$ indicating a successful application of the technique (Fig. 2C).

\subsection{Environmental samples}

Hanford subsurface injection water samples were collected specifically for testing the IMS technique during the ongoing $\mathrm{HRC}^{\circledR}$ biostimulation. A cell count of the water sample received revealed $1 \times 10^{6}$ cells $\mathrm{ml}^{-1}$. This water sample was further concentrated by centrifugation $\left(1.8 \times 10^{7}\right.$ cells $\left.\mathrm{ml}^{-1}\right)$. Following IMS treatment, the cell density of Desulfovibrio-like cells recovered was $5.4 \times 10^{5}$ cells $\mathrm{ml}^{-1}$ (also see Fig. 3A-C). Viability of IMS-treated and recovered Desulfovibrio-like cells was tested by inoculation into LS4D medium. The cells grew normally, i.e., they reduced sulfate visibly leading to iron sulfide precipitation in less than $72 \mathrm{~h}$. In $96 \mathrm{~h}$, the optical density (O.D.600) reached 0.523 .

Microbial cells were also separated from the soil slurries of heavy metals and radionuclides contaminated samples from Germany. IMS treatment and separation yielded Desulfovibrio-like cells for both soil horizons (Fig. 4). Separated microbes from Btlc and BrI were then inoculated in LS4D medium. These enrichments reduced eventually $14.5 \mathrm{mM}$ and $15.0 \mathrm{mM}$ sulfate, respectively, demonstrating that the separated cells were viable.

\section{Conclusions}

Immunomagnetic separation (IMS), a rapid, specific, efficient, and technically simple method has been used for the separation of a target organism directly from a consortium of non-target organisms or other particles. While the technique has been applied successfully to detect and separate easy to grow microbes like E. coli and Listeria, it has not been used for environmental anaerobic bacteria that have stringent growth and handling requirements. The microorganisms described in this paper are strictly anaerobic. We developed a protocol to specifically separate cells of $D$. vulgaris from laboratory-scale model experiments and subsurface environmental samples. The results demonstrate that this tool is powerful enough to separate $D$. vulgaris and closely related Dv-like cells from a consortium of several microorganisms. Preliminary, functional gene microarray analysis (Geochip) of IMS-separated Desulfovibrio-like cells were compared with lab grown mid-log phase cells of $D$ vulgaris strain Hildenborough. It was possible to obtain good quality RNA from field-separated Desulfovibrio-like cells and patterns in gene expression of some key metabolic and ribosomal genes were apparent (Aifen Zhou, Jizhong Zhou; University of Oklahoma personal communication). The latter demonstrates that IMS can be effectively used in conjunction with transcriptomics analysis of the separated target cells. A field deployable version of IMS will allow for a timely analysis of changing gene profiles of organisms as they are exposed to fluctuating factors in the environment, be it response to changing temperature, $\mathrm{pH}$, growth substrates, electron acceptors or nutrient fluxes. The IMS technique as developed for anaerobes like D. vulgaris cells is non-destructive and is successful in yielding cells that can be processed for critical-omics analysis downstream. The rapid separation and detection do not require expensive equipment. It is relatively simple and can be modified in the separation or detection (followed by imaging or specific enzyme tests/culture based methods) of multiple bacterial species simultaneously.

However, since this separation technique depends on antibodies developed against target microbes, IMS can only be used for organisms available as pure culture. Further, while this technique works very well for planktonic cells, separation and detection from biofilms may present additional challenges due to the nature of the extracellular polymeric substances. There could also exist some degree of cross reactivity with closely related species.

In further development, we will target other environmental microorganisms of interest with bioremediation capabilities and scale down the protocol for field deployment and in support of various -omics studies especially from low-biomass critical environments.

\section{Acknowledgements}

This work conducted by ENIGMA (http://enigma.lbl.gov/) was supported by the Office of Science, Office of Biological and Environmental Research, of the U.S. Department of Energy under Contract No. DE-AC02-05CH11231. We would like to thank My Vu Nguyen for her assistance in performing the experiments.

\section{References}

Ayaz, N.D., Ayaz, Y., Kaplan, Y.Z., Dogru, A.K., Aksoy, M.H., 2009. Rapid detection of Listeria monocytogenes in chicken carcasses by IMS-PCR. Ann. Microbiol. 59, $741-744$.

Beyor, N., Yi, L., Seo, T.S., Mathies, R.A., 2009. Integrated capture, concentration, polymerase chain reaction, and capillary electrophoretic analysis of pathogens on a chip. Anal. Chem. 81, 3523-3528.

Burkhardt, E.-M., Akob, D.M., Bischoff, S., Sitte, J., Kostka, J.E., Banerjee, D., Scheinost, A.C., Küsel, K., 2010. Impact of biostimulated redox processes on metal dynamics in an iron-rich creek soil of a former uranium mining area. Environ. Sci. Technol. 44, 177-183.

Bushon, R.N., Brady, A.M., Likirdopulos, C.A., Cireddu, J.V., 2009. Rapid detection of Escherichia coli and enterococci in recreational water using an immunomagnetic separation/adenosine triphosphate technique. J. Appl. Microbiol. 106, 432-441.

Chakraborty, R., Coates, J.D., 2004. Anaerobic degradation of monoaromatic hydrocarbons. Appl. Microbiol. Biotech. 64, 437-446.

Chang, Y.-J., Peacock, A.D., Long, P.E., Stephen, J.R., McKinley, J.P., Macnaughton, S.J., Anwar Hussain, A.K.M., Saxton, A.M., White, D.C., 2001. Diversity and characterization of sulfate-reducing bacteria in groundwater at a uranium mill tailings site. Appl. Environ. Microbiol. 67, 3149-3160.

Chapman, P.A., Ellin, M., Ashton, R., 2001. Comparison of culture, PCR and immunoassays for detecting Escherichia coli 0157 following enrichment culture and immunomagnetic separation performed on naturally contaminated raw meat products. Int. J. Food Microbiol. 68, 11-20.

Foddai, A., Elliott, C.T., Grant, I.R., 2010. Maximizing capture efficiency and specificity of magnetic separation for Mycobacterium avium subsp paratuberculosis cells. Appl. Environ. Microbiol. 76, 7550-7558.

Gasanov, U., Hughes, D., Hansbro, P.M., 2005. Methods for the isolation and identification of Listeria spp. and Listeria monocytogenes: a review. FEMS Microbiol. Rev. 29, 851-875.

Han, R., Geller, J.T., Yang, L., Brodie, E.L., Chakraborty, R., Larsen, J.T., Beller, H.R., 2010. Physiological and transcriptional studies of $\mathrm{Cr}(\mathrm{VI})$ reduction under aerobic and denitrifying conditions by an aquifer-derived Pseudomonad. Environ. Sci. Technol. 44, 7491-7497.

Hemme, C.L., Deng, Y., Gentry, T.J., Fields, M.W., Wu, L., Barua, S., Barry, K., Tringe, S.G., Watson, D.B., He, Z., Hazen, T.C., Tiedje, J.M., Rubin, E.M., Zhou, J., 2010. ISME J. 4, 660-672. 
Kaksonen, A.H., Plumb, J.J., Franzmann, P.D., Puhakka, J.A., 2004. Simple organic electron donors support diverse sulfate-reducing communities in fluidized-bed reactors treating acidic metal- and sulfate-containing wastewater. FEMS Microbiol. Ecol. 47, 279-289.

Klonowska, A. Clark, M.E., Thieman, S.B., Giles, B.J., Wall, J.D., Fields, M.W., 2008 Hexavalent chromium reduction in Desulfovibrio vulgaris Hildenborough causes transitory inhibition of sulfate reduction and cell growth. Appl. Microbiol. Cell Physiol. 78, 1007-1016.

Lindqvist, R., Antonsson, A.K., Norling, B., Persson, L., Ekstrom, A.C.L., Fager, U., Eriksson, E., Lofdah, S., Norberg, P., 1998. The prevalence of verocytotoxin-producing Escherichia coli (VTEC) and E-coli 0157: H7 in beef in Sweden determined by PCR assays and an immuno-magnetic separation (IMS) method. Food Microbiol. 15, 591-601.

Lovley, D.R., 1993. Dissimilatory metal reduction. Annu. Rev. Microbiol. 47, 263-290.

Mercanoglu, B., Griffiths, M.W., 2005. Combination of immunomagnetic separation with real-time PCR for rapid detection of Salmonella in milk, ground beef, and alfalfa sprouts. J. Food Prot. 68, 557-561.

Miyatake, T., MacGregor, B.J., Boschker, H.T., 2009. Linking microbial community function to phylogeny of sulfate-reducing Deltaproteobacteria in marine sediments by combining stable isotope probing with magnetic-bead capture hybridization of 16S rRNA. Appl. Environ. Microbiol. 75, 4927-4935.

Mukhopadhyay, A., He, Z., Alm, E.J., Arkin, A.P., Baidoo, E.E., Borglin, S.E., Chen, W., Hazen, T.C., He, Q., Holman, H.Y., Huang, K., Huang, R., Joyner, D.C., Katz, N., Keller, M., Oeller, P., Redding, A., Sun, J., Wall, J., Wei, J., Yang, Z., Yen, H.C., Zhou, J., Keasling, J.D., 2006. Salt stress in Desulfovibrio vulgaris Hildenborough: an integrated genomics approach. J. Bacteriol. 188, 4068-4078.

Olsvik, O., Popovic, T., Skjerve, E., Cudjoe, K.S., Hornes, E., Ugelstad, J., Uhlén, M., 1994. Magnetic separation techniques in diagnostic microbiology. Clin. Microbiol. Rev. 7, 43-54.

Perez, R.M., Cabrera, G., Gomez, J.M., Abalos, A., Cantero, D., 2010. Combined strategy for the precipitation of heavy metals and biodegradation of petroleum in industrial wastewaters. J. Hazard. Mater. 182, 896-902.

Phillips, E.J., Landa, E.R., Lovley, D.R., 1995. Remediation of uranium contaminated soils with bicarbonate extraction and microbial U (VI) reduction. J. Ind. Microbiol. 14, 203-207.
Qiu, J., Zhou, Y., Chen, H., Lin, J.M., 2009. Immunomagnetic separation and rapid detection of bacteria using bioluminescence and microfluidics. Talanta 79 787-795.

Rabus, R., Hansen, T., Widdle, F., 2006. Dissimilatory sulfate- and sulfur-reducing prokaryotes, In: Dworkin, M., Falkow, S., Rosenberg, E., Schleifer, K.H., Stackebrandt, E. (Eds.), The prokaryotes: an evolving electronic resource for the microbiological community, 3rd edition. Springer-Verlag, New York. release 3.3.

Sitte, J., Akob, D.M., Kaufmann, C., Finster, K., Banerjee, D., Burkhardt, E.-M., Kostka, J.E. Scheinost, A.C., Büchel, G., Küsel, K., 2010. Microbial links between sulfate reduction and metal retention in uranium- and heavy metal-contaminated soil. Appl. Environ. Microbiol. 76, 3143-3152.

Sivagnanam, V., Song, B., Vandevyver, C., Bunzli, J.C.G., Gijst, M.A.M., 2010. Selective breast cancer cell capture, culture, and immunocytochemical analysis using selfassembled magnetic bead patterns in a microfluidic chip. Langmuir 26, 6091-6096.

Su, X.L., Li, Y., 2004. Quantum dot biolabeling coupled with immunomagnetic separation for detection of Escherichia coli 0157:H7. Anal. Chem. 76, 4806-4810.

Tabatabai, M.A., 1974. Determination of sulfate in water samples. Sulphur Inst. J. 10, 11-13.

Uyttendaele, M., Van Hoorde, I., Debevere, J., 2000. The use of immuno-magnetic separation (IMS) as a tool in a sample preparation method for direct detection of L-monocytogenes in cheese. Int. J. Food Microbiol. 54, 205-212.

Wadud, S., Leon-Velarde, C.G., Larson, N., Odumeru, J.A., 2010. Evaluation of immunomagnetic separation in combination with ALOA Listeria chromogenic agar for the isolation and identification of Listeria monocytogenes in ready-to-eat foods. J. Microbiol. Methods 81, 153-159.

Wei, N., Finneran, K.T., 2009. Microbial community analyses of three distinct, liquid cultures that degrade methyl tert-butyl ether using anaerobic metabolism. Biodegradation 20, 695-707.

Zuo, R., Ornek, D., Syrett, B.C., Green, R.M., Hsu, C.H., Mansfeld, F.B., Wood, T.K., 2004. Inhibiting mild steel corrosion from sulfate-reducing bacteria using antimicrobialproducing biofilms in Three-Mile-Island process water. Appl. Microbiol. Biotech. 64, 275-283. 


\section{DISCLAIMER}

This document was prepared as an account of work sponsored by the United States Government. While this document is believed to contain correct information, neither the United States Government nor any agency thereof, nor The Regents of the University of California, nor any of their employees, makes any warranty, express or implied, or assumes any legal responsibility for the accuracy, completeness, or usefulness of any information, apparatus, product, or process disclosed, or represents that its use would not infringe privately owned rights. Reference herein to any specific commercial product, process, or service by its trade name, trademark, manufacturer, or otherwise, does not necessarily constitute or imply its endorsement, recommendation, or favoring by the United States Government or any agency thereof, or The Regents of the University of California. The views and opinions of authors expressed herein do not necessarily state or reflect those of the United States Government or any agency thereof or The Regents of the University of California.

Ernest Orlando Lawrence Berkeley National Laboratory is an equal opportunity employer. 